\title{
Anthós
}

$7-2012$

\section{Jacques Ranciere's Politics of Literature, Writing and Aesthetics in the Letters of John Keats}

Darcie Hart Riedner

Portland State University

Follow this and additional works at: https://pdxscholar.library.pdx.edu/anthos

Part of the Comparative Literature Commons

Let us know how access to this document benefits you.

\section{Recommended Citation}

Riedner, Darcie Hart (2012) "Jacques Ranciere's Politics of Literature, Writing and Aesthetics in the Letters of John Keats," Anthós: Vol. 4: Iss. 1, Article 5.

https://doi.org/10.15760/anthos.2012.75

This open access Article is distributed under the terms of the Creative Commons Attribution-NonCommercialShareAlike 4.0 International License (CC BY-NC-SA 4.0). All documents in PDXScholar should meet accessibility standards. If we can make this document more accessible to you, contact our team. 
Riedner 1

Darcie Hart Riedner

Jacques Ranciere’s Politics of Literature, Writing and Aesthetics in the Letters of John Keats

When I have fears that I may ceace to be, Before my pen has gleaned my teaming brain.

- $\underline{\text { John Keats }}$

Through his numerous works on the philosophy of aesthetics, literature and writing Jacques Rancière has crafted a body of work based on the premise of equality as recognized through aesthetics. In the introduction to the English translation of Rancière’s The Politics of Aesthetics, author Gabriel Rockhill writes Rancière supports abolishing “any presupposed inequalities of intelligence” (Rockhill 2). Rancière argues against any “privileged position usurped by philosophy in its various attempts to speak for others, be it the proletariat, the poor, or anyone else who is not 'destined to think”’(Rockhill 2) Rancière’s political positioning of aesthetics finds "those who have no name, who remain invisible and inaudible, can only penetrate the police order [politics] via a mode of subjectivization that transforms the aesthetic coordinators of the community by implementing the universal presupposition of politics: we are all equal.(Rockhill 3). I suggest Rancière’s theories on the politics of aesthetics, literature and writing are present in letters written by $19^{\text {th }}$ century Romantic poet John Keats.

Rancière defines literature by nineteenth century standards ...“ it shed its old meaning, as the knowledge held by men of letters, and came to refer to the art of writing itself” (Politics of Literature 4). Two of Keats primary philosophies of poetry, the camelion poet and negative 
capability are supported by Rancière's theory of the distribution of the perceptible [sensible] and his idea of flesh of words. In a letter to his publisher's legal and literary advisor, Richard Woodhouse, Keats identifies himself as a "camelion Poet” with an identity created by his poetry: "it is not itself-it has no self-it is every thing and nothing-It has no character-it enjoys light and shade; it lives in gusto, be it foul or fair, high or low, rich or poor, mean or elevated-...It does no harm from its relish of the dark side of things than any more from the its tastes for the bright ones; because they both end in speculation”(Longman 958). Literature [writing] occupies a fundamental space in Rancière's theory of the distribution of the perceptible[sensible]: "The expression 'politics of literature' thereby implies that literature intervenes in ... carving up of space and time, the visible and invisible, speech and noise. It intervenes in the relationship between practices and forms of visibility and modes of saying that carves up one of more common worlds" ( Politics of Literature 4). Rancière’s distribution of the sensible and Keats poetic self-identity exist within the same sphere of duality, each only actualized through literature. As a camelion poet Keats is invisible until he appears in the words he writes on a page; his thoughts are just noise until they become the speech of a poet. This is the intervention of literature, as Rancière envisions it, in the realm of the political. Keats carries the application of the camelion poet, or the manner in which he defines himself, even further in a letter he wrote his brothers in December of 1817 about negative capability, a quality Keats felt necessary for a man to be a success in Literature: "when man is capable of being in uncertainties, Mysteries, doubts, without any irritable reaching after fact and reason” (Longman 952). Keats idea of the necessity of a poet to exist outside the tether of the specific is reflected in Rancière's The Flesh of Words, 
as he considers the role of lyric poetry in politics: “The fundamental axis of the poetic-political relationship is thus not the one where the "truth" of the utterance depends on the "quality" of which is represented. It rests in the method of presentation, in the way in which utterance makes itself present, imposes the recognition of immediate meaning in the sensory”(Flesh of Words 14). Depending on the immediate and the sensory inhabit both philosophies, reflecting what Rancière called the purity of the art [writing] and Keats associated in his December 1817 letter with an intensity he felt art must possess and a successful writer's ability to rely on his senses rather than reason. In a letter to Benjamin Bailey in November 1817, Keats reiterates his dependence on his senses, his preferred method of presentation; “ I am certain of nothing but of the holiness of the Heart's affections and the truth of Imagination- What the imagination seizes as beauty must be truth”(Longman, 950). Keats sees his existence defined by what he has written and Rancière views what is written [literature] necessary in defining the perceptible, the existing.

Rancière’s definitions of politics and police are significant in Keats nineteenth century existence as a poet. Rancière's definition of police, as explained in the translator's introduction in The Politics of Aesthetics, is:

an organizational system of coordinates that establishes a distribution of the sensible or a law that divides the community into groups, social positions and functions. This law implicitly separates those who take part from those who are excluded and it therefore presupposes a prior aesthetic division between the 
visible and the invisible, the audible and the inaudible, the sayable and the unsayable. (3)

For Keats, critics and the old guard of the first generation of Romantic poets, in particular William Wordsworth, assume the role of the police. Keats, as a fledgling member of the literati of the day was the physical definition of Rancière's politics: "The essence of politics consists in interrupting the distribution of the sensible by supplementing it with those who have no part in the perceptual coordinates of the community"(Rockhill 3). Keats' letters are an expression of his work as a poet, containing his ever evolving thoughts and insight as he was developing his poetic theory, trying to find his place in the body politic of literature in the nineteenth-century. His letters also bear witness to his widely vacillating opinion on Wordsworth as he wrestled with the reverence he felt at times for Wordsworth as well as resentment he carried due to the darkness cast by Wordsworth iconic shadow.

While Rancière points out politics of literature is not the same as the politics of the individual writer, their involvement in social or political struggles or the manner in which political ideology of the day is represented in their particular work, Keats life, his personal situation was intrinsically political particularly when referenced to Rancière's universal presupposition of politics: we are all equal. This is evident in 1817, in the critique of Keats first published volume, Poems: "Poems was ridiculed in terms marked by social snobbery and political prejudice ... Though he had anticipated this reception he was stung by the intensity of the venom in the ridicule”(Wolfson, Introduction). 
The social and political nature of the attack on Keats, his poetry and his circle of literary friends reached its zenith in October of that year in an article in Blackwood's Edinburgh Magazine titled “On the Cockney School of Poetry”. While directed primarily at journalist and newspaper editor Leigh Hunt, the article sparred none of those who moved within Hunt's circle of influence, including Keats. For the author of the article Cockney represented suburban vulgarity (Daisy Hay, The Young Romantics 134) and a Cockney was “excluded at birth from the lofty realms of poetry, which were reserved for those who had received a Classical education” (Andrew Motion, Keats 204). The criticism of Keats writing based on his unfit nature to be a poet signifies Rancière’s distribution of the perceptible; “it makes visible what was invisible, it makes audible speaking beings those who were previously heard only as noisy animals”(Politics of Literature 4). In a letter to friend Benjamin Bailey in November, 1817 Keats wrote of the first Cockney article: “ I don’t mind the thing much-but if he [author of the article] should go to such lengths with me as he had done with Hunt, I must infallibly call him to an account [duel]...I don’t relish his abuse”(Wolfson 67).

It was not the last critical attack on Keats by Blackwood's. The second was directed at Keats's Endymion in the spring of 1818. The attack was again virulent and personal as "Keats was mocked for his Cockney incomprehension of the Classics, for his adherence to the 'Cockney School of Politics, as well as the Cockney School of Poetry'” (Hay 135). While Blackwood's did criticize the form used by Keats in writing the poem, the assault centered more on personal than poetic flaws, calling him immature and ignorant. The Quarterly Review also dismissed 
Endymion in a review which was somewhat less socially biased but by the critic pointing out he was “exasperated by the vulgar and subversive style of the poem”(Motion 301), his comments were still directed at Keats’ background and education.

In discussing the place of lyrical poetry in The Politics of Writing, Rancière addresses the "method of utterance” by the poet particularly " the way in which the poet....relates to the subject of the poem, identifies with it, differentiates himself from it or hides himself behind it”( Politics of Writing 11). Keats was vitally aware of his voice as a poet. In responding to the critics of Endymion, Keats wrote his publisher James Hessey; “...it is not in my nature to fumble-I will write independently.-I have written independently without Judgement-I may write independently \& with judgement hereafter.-The Genius of Poetry must work out its own salvation in a man: It cannot be matured by law \& precept, but by sensation \& watchfulness in itself” (Motion 303). Keats defended his own "method of utterance” and continued his political process of writing, rallying against the police of criticism.

Keats political participation [writing] in relation to the poetical monarchy, the police, of William Wordsworth is more complex. In making the decision to abandon his initial career choice of medicine Keats decided "he would heal the mind-by addressing the nature and purpose of suffering, by developing the Wordsworthian idea that 'poetry depended upon a condition of positive health in the poet' and by regarding poetry itself as a salubriously redemptive force-a friend/To soothe the cares, and lift the thoughts of man'”(Motion 131). 
Meeting Benjamin Haydon in 1816 gave Keats unexpected access to Wordsworth. In a message to Haydon following an evening at his home, Keats enclosed the beginning of Sonnet XIV. Haydon, in turn, told Keats he would send it to his friend, Wordsworth. Keats wrote to Haydon; “The idea of your sending it to Wordsworth put me out of breath”(Wolfson 5). But Wordsworth 's response to the young talent was tepid at best, saying he was not an "impartial” judge he deemed Keats sonnet “assuredly vigorously conceived, well expressed and agreeably concluded”(Wolfson 5).

Keats continued his poetical writing, "participating in a shared world” (Politics of Literature 4) orbiting in Wordsworth’s sphere. He met Wordsworth in 1817 and despite several awkward meetings and dinners developed a personal but not close relationship with the legendary poet. Keats literary reaction to Wordsworth in letters to friends and family discusses his ideas of the egotistical sublime as well as Wordsworth's genius in relation to his own future writing. As mentioned earlier, in a letter to Richard Woodhouse in October 1818 Keats discusses what he feels to be his poetic nature, calling himself a camelion. He contrasts this to the wordsworthian or egotistical sublime of Wordsworth himself, in reference not only to the older poet's personality but the visibility of his identity, his biases and philosophy visible through his work (Longman, 958). Wordsworth ego occupies Keats letter to John Hamilton Reynolds earlier in 1818; “are we to be bullied into a certain Philosophy engendered in the whims of an egotist-Every Man has his speculations, but every Man does not brood and peacock over them til he makes a false coinage and deceives himself”(Longman 952). In dismissing the 
overriding presence of Wordsworth's ego in his poetry, Keats embodies the idea of the aesthetic regime Rancière discusses in The Politics of Aesthetics; "The aesthetic state is a pure instance of suspension, a moment when form is experienced for itself. Moreover, it is the moment of the formation and education of a specific type of humanity”(The Politics of Aesthetics, 24). Keats struggled with Wordsworth's representation of himself in his poetry until he finally comes to terms with "Wordsworth genius" as expressed in a letter to John Hamilton Reynolds; "we found what he says true as far as we have experienced and we can judge no further”(Longman 955).

Keats body of more than 200 letters written from 1816 to 1820, are an extension of his poetical and literary self. He expresses views on, techné , criticism, poetical character and the truth and beauty with which he viewed his writing and the manner in which these thoughts dominated his life. In doing so, he became the physical representation of the thoughts and philosophies Jacques Ranciére would express two centuries later in his project on the politics of aesthetics, literature and writing. 


\section{Works Cited}

Damrosch, David, and Susan J. Wolfson. "John Keats." The Longman Anthology of British Literature. 4th ed. Vol. 2A. New York: Longman, 2010. 950-65. Print.

Hay, Daisy. Young Romantics: the Tangled Lives of English Poetry's Greatest Generation. New York: Farrar, Straus and Giroux, 2010. Print.

Motion, Andrew Peter. Keats. London: Faber and Faber, 1997. Print.

Rancière, Jacques and Charlotte Mandell. The Flesh of Words: the Politics of Writing. Stanford, CA: Stanford UP, 2004. Print.

Rancière, Jacques, Gabriel Rockhill, and Slavo J. Zizek. "Jacques Rancière's Politics of Perception." Introduction. The Politics of Aesthetics: The Distribution of the Sensible. London: Continuum, 2006. 1-6. Print.

Rancière, Jacques, Gabriel Rockhill, and Slavoj Žižek. The Politics of Aesthetics: The Distribution of the Sensible. London: Continuum, 2006. Print.

Rancière, Jacques, and Julie Rose. "Hypotheses." Politics of Literature. Cambridge: Polity, 2011. 3-29. Print.

Wolfson, Susan J. John Keats. New York: Longman, 2007. Print. Wolfson, Susan J. John Keats. New York: Longman, 2007. Print. Wolfson, Susan J. John Keats. New York: Longman, 2007. Print. 